\title{
TRINIDAD Y TOBAGO 20 ANIVERSARIO DE LA OMS
}

\author{
NOGUERA-PALAU JJ ${ }^{1}$
}

Cuando en 1945 se creó la Organización de las Naciones Unidas, uno de sus primeros compromisos fue la fundación de un sistema administrativo que velara por la salud mundial. El siete de abril de 1948 quedó constituida, con sede en Ginebra, la Organización Mundial de la Salud como autoridad directiva y coordinadora en materia de labor sanitaria mundial.

Trinidad y Tobago es una república sudamericana perteneciente a la Commonwealth desde 1962; se trata de un archipiélago compuesto por las islas de estos mismos nombres y otras 21 menores situa- das cerca de la costa nororiental venezolana. La isla de Trinidad, a la que Cristóbal Colón llegó en su tercer viaje al Nuevo Mundo el 31 de julio de 1498, está a $15 \mathrm{~km}$ de Venezuela, tiene una superficie de unos $4800 \mathrm{~km}^{2}$ y su capital, y mayor ciudad, es Puerto España. A $36 \mathrm{~km}$ al noreste de Trinidad se sitúa Tobago cuya extensión es de solo 300 km².

El año 1968, conmemorando el 20 aniversario de la OMS, Trinidad y Tobago emitió una serie de tres sellos en los que se muestra la exploración de la agudeza visual a una muchacha.

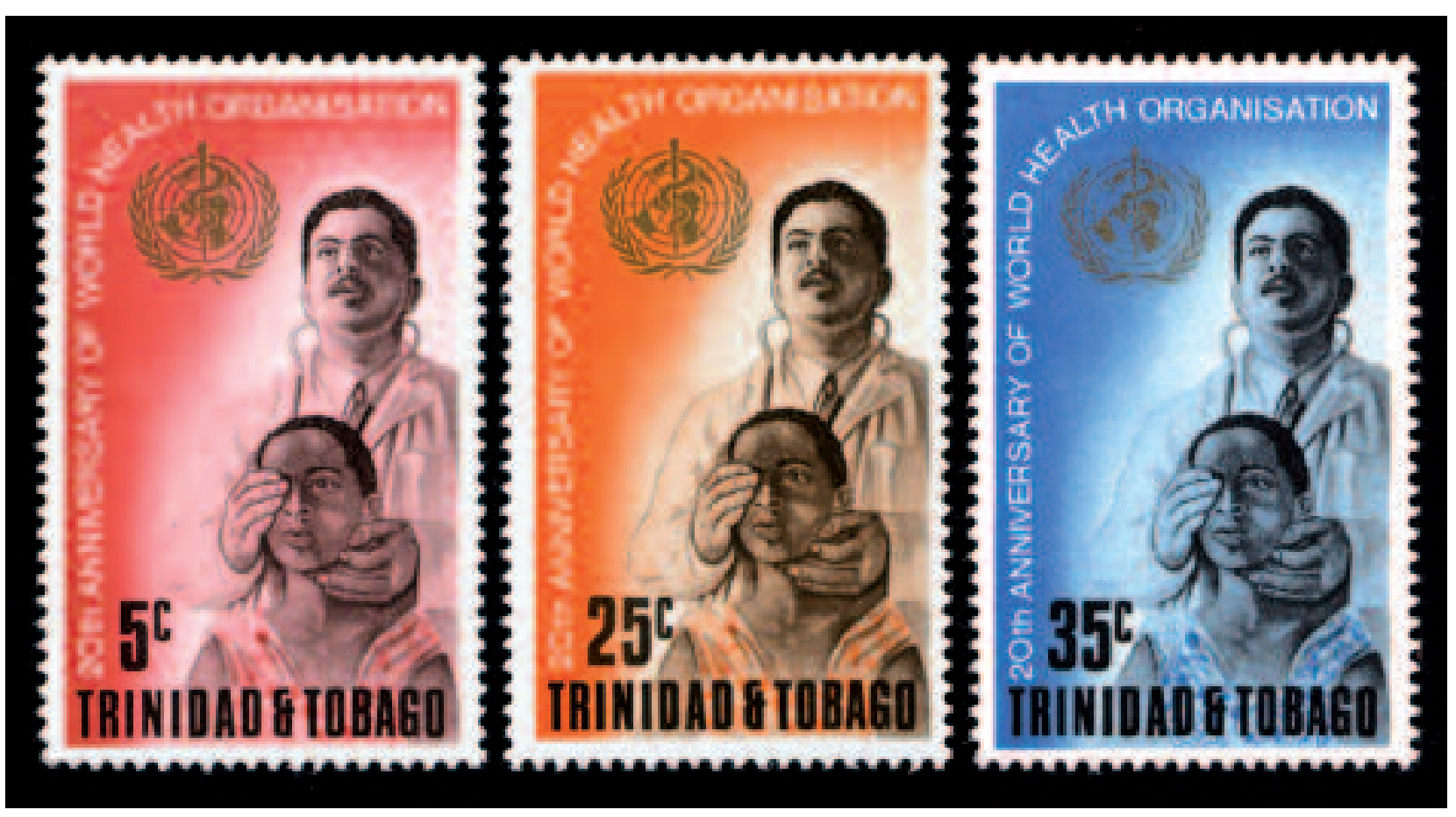

Trinidad y Tobago, 1968 - Yvert 220/22.

\footnotetext{
1 Oftalmólogo. Pamplona.

E-mail: jnoguera72b@terra.es
} 